УДК 903'1 (= 56) $(571.56+571.65)$

\title{
ПРОБЛЕМА ПРОИСХОЖДЕНИЯ ПАЛЕОЭСКИМОССКИХ КУЛЬТУР И ПОЯВЛЕНИЯ ИХ СТОЯНОК НА СЕВЕРО-ВОСТОКЕ РОССИИ
}

\author{
А. И. Лебединцев
}

\author{
ФГБУН Северо-Восточный комплексный научно-исследовательский институт \\ им. Н. А. Шило ДВО РАН, г. Магадан \\ E-mail: lebedintsev@neisri.ru
}

\begin{abstract}
Рассмотрена проблема происхождения палеоэскимосов. Миграция предков палеоэскимосов на Американский континент произошла в период 7500-5500 кал. л. н. Основой развития палеоэскимосских культур стала «арктическая традиция малых орудий» (“Arctic Small Tool tradition”). В генофонде палеоэскимосов выявлен геном древнего палеосибирского (индивид с Дуванного Яра, Нижнеколымский район Якутии) и восточноазиатского населения, близкого индивидам из пещеры Чертовы Ворота в Приморье и захоронения китойской культуры в Забайкалье. Основные черты палеэскимосской традиции появляются уже на раннем этапе (культуры Пре-Дорсет, Индепенденс I, Саккак). Появление палеоэскимосской традиции на крайнем Северо-Востоке Азии связано с экспансией палеоэскимосских групп Канадской Арктики и Гренландии в район Берингоморья примерно 3500 кал. л. н. К палеоэскимосскому периоду относятся временная сезонная стоянка Чертов Овраг на о. Врангеля и поселение Уненен, расположенное на южной оконечности Чукотского полуострова. Токаревская культура может быть отнесена к кругу палеоэскимосских культур или связана с палеоэскоалеутской миграцией с Юго-Западной Аляски и Алеутских островов.
\end{abstract}

Ключевые слова: происхождение палеоэскимосских культур, стоянки палеоэскимосской традиции, Северо-Восток России.

DOI: 10.34078/1814-0998-2020-1-117-127

Эскимосская проблема все еще далека от разрешения. Большинство исследователей считают, что центр формирования популяции эскимосов находился на Юго-Западной Аляске, откуда во II тыс. до н. э. могло начаться их движение в сторону Берингова пролива (Александров и др., 1982).

К палеоэскимосской традиции (примерно 3200 г. до н. э. -1300 г. н. э.) относят комплекс Денби-Флинт, поселение Древнекитобойной культуры на м. Крузенштерн, культуры Чорис, Нортон и Ипиутак на Аляске, культуры Саккак, Индепенденс I, II, Пре-Дорсет и Дорсет в Канадской Арктике и Гренландии (Encyclopedia..., 2001; The Oxford..., 2016).

Палеоэскимосские культуры развиваются на основе «арктической традиции малых орудий» (ASTt), к которой относятся комплекс Денби-Флинт на Аляске, ранние палеоэскимосские культуры Канадской Арктики и Гренландии (Саккак, Индепенденс I, Пре-Дорсет). Происхождение традиции ASTt связывают с экспансией через Берингов пролив носителей древних культур крайнего Северо-Востока Азии, археологи-

(С Лебединцев А. И., 2020 ческие комплексы которых обнаруживают сходства с индустрией комплекса Денби-Флинт (Роwers, Richard 1990. P. 666).

Носителей традиции ASTt в Канадской Apктике возрастом ранее 4500-4400 кал. л. н. ряд исследователей объединяют под наименованием «Начальный Пре-Дорсет» (Friesen, 2016. Р. 676). На его основе в Канадской Арктике и Гренландии возникли последующие палеоэскимосские культуры: Пре-Дорсет (4500-2700 кал. л. н.), Индепенденс I (4500-3800 кал. л. н.) и Саккак (4500-2800 кал. л. н.). Памятники Индепенденс I и Пре-Дорсет широко распространены в восточной части Канадской Арктики, а стоянки Саккак встречаются в основном в Гренландии (Первоначальное..., 2014. С. 293). По мнению МакГи (McGhee, 1979), первая миграция в Канадскую Арктику была носителей культуры Индепенденс I, а за ней последовала пре-дорсетская экспансия. Дж. Росс считает, что носители ПреДорсет и Индепенденс I проникли в Канадскую Арктику одновременно и заняли разные районы (Первоначальное..., 2014. С. 306). Технология и типология каменного инвентаря в культурах Саккак и Индепенденс I сходны, но между этими ин- 
дустриями различия в принципах изготовления орудий, указывающие на существование локальных традиций (Sørensen, 2010). Характерными чертами этих культур являются: каменные орудия мелкого размера; миниатюрные иглы из кости; использование лодок и гарпунного комплекса для морского зверобойного промысла, включающего поворотные и зубчатые наконечники гарпунов; лук и стрелы для охоты на оленя и овцебыка; устройство жилища с выложенным по центру проходом; наличие прямоугольного очага; отсутствие технологий гончарного производства.

Расхождение протоэскимосского и протоалеутского языков произошло около 4000 л. н. (Fortescue, 1998; Berge, 2016). Эскимосская ветвь эскимосско-алеутской языковой семьи представлена инуитской группой языков, распространенных на Аляске, в Канаде и Гренландии, и юпикской группой языков - в западной части Аляски и на Чукотке. Сиреникский язык, вероятно, является результатом миграции палеоэскимосских групп из Аляски, что археологически проявляется в развитии палеоэскимосской традиции на Чукотке начиная с 3.500 кал. л. н.

К палеоэскимосскому периоду относится временная сезонная стоянка Чертов Овраг на о. Врангеля, датируемая концом II тыс. до н. э. началом I тыс. до н. э. (Диков, 1979; Теин, 1983; Герасимов и др., 2003) или, скорее всего, началом I тыс. до н. э. (Питулько, 2003. С. 105). Древние морские охотники появились на острове, вероятно, в результате охотничьего преследования мигрирующих моржей, направляющихся к крупнейшему лежбищу на м. Блоссом.

Остается открытым вопрос истоков этой древнейшей культуры морских зверобоев на о. Врангеля. Н. Н. Диков (1979. С. 168), основываясь на сходстве каменного и костяного инвентаря этой стоянки с материалами из Канадской Арктики и Гренландии, относил ее к памятникам палеоэскимосского круга. Позднее он уточнил, что эти палеоэскимосские культуры были распространены по обе стороны Берингова пролива, куда входили на тот момент Древнекитобойная культура, Чорис, Нортон на Аляске и Врангелевская стоянка - на Чукотке (Диков, 1993. С. 162). Т. С. Теин (1979) связывал происхождение памятника с результатом прямой миграции из Северной Америки и Гренландии. В. В. Питулько (2001) также высказал мнение, что идея о неазиатском происхождении врангелевского комплекса кажется более предпочтительной. Р. Аккерман (Ackerman, 1988. Р. 66-67) отметил некоторые сходные черты коллекции стоянки Чертов Овраг с материалами Древнекитобойной культуры на Аляске. Он также высказал предположение, что охотники с о. Врангеля и м. Крузенштерн могли иметь общего, но еще неизвестного предка. По его мнению, эти стоянки являлись ответвлениями от восточной экспансии традиции Индепенденс I в регионе Чукотского моря или более поздним продолжением этой адаптации в высокоширотной Арктике (Ackerman, 1998. С. 255). Сомнения в этой гипотезе были высказаны С. В. Гусевым (2010. C. 208). Также отмечалось, что носители Древнекитобойной культуры происходили от другой традиции, чем население ASTt (Giddings, Anderson, 1986. Р. 332).

H. Н. Диков (Dikov, 1988) отмечает сходство врангелевского наконечника поворотного гарпуна с аналогичной находкой из Усть-Бельского могильника. Врангелевский наконечник сопоставлялся с наконечником культуры Нортон (Лебединцев, 1990). Гипотеза о принадлежности стоянки Чертов Овраг на о. Врангеля к Древнекитобойной культуре с Аляски, по мнению санктпетербургских исследователей (Герасимов и др., 2003), требует более веских доказательств. Была предпринята попытка проследить возможную связь врангелевской палеоэскимосской культуры с поздним неолитом Северной Чукотки (Питулько, 1990). В. В. Питулько (2003), упомянув о том, что каменные изделия стоянки Чертов Овраг близко напоминают находки северочукотской и усть-бельской культур, составляющих, по его мнению, чукотский вариант ымыяхтахской культуры, считает вполне реальным формирование врангелевского комплекса на местной ымыяхтахской традиции. Пока что это предположение только постулируется. Об азиатских корнях врангелевской палеоэскимосской культуры упоминал Т. С. Теин (1979. С. 76). Высказывалось предположение, что о. Врангеля посещали группы охотников азиатского побережья (Питулько, 1998. С. 101). В. В. Питулько (2003. С. 134) считает возможным, что стоянка Чертов Овраг теснейшим образом связана со стоянкой Аачимбаза, имеющей датировку $2890 \pm 220$ (ЛУ-4480). Предположение о том, что она является частью древнейшего единого и широкого культурного пласта Тихоокеанского Севера, в том числе и с его азиатской стороной, высказывал Н. Н. Диков (1979. С. 168).

Врангелевский наконечник отличается от гренландского (культура Индепендес II): у него одна боковая шпора в основании и желобок для крепления, а у гренландского две симметричные шпоры, желобок в нижней части отсутствует. По ряду признаков (одна боковая шпора, открытое гнездо для колка, одно отверстие для линя, желобок для крепления в нижней части) врангелевский наконечник может быть сопоставим с наконечником культуры Нортон (Giddings, 1964. P. 36. Fig. 18). К этому же мнению приходит японский исследователь К. Ямаура (Yamaura, 1980. Р. 17). Также следует отметить, что в культуре Индепенденс II имеются и другие наконечники 
гарпунов поворотного типа с открытым и закрытым гнездом (Fitzhugh, 1984. Fig. 6).

H. Н. Диков (Dikov, 1988) отмечает сходство врангелевского наконечника гарпуна с наконечником из Усть-Бельского могильника, датируемого началом I тыс. до н. э. Единичность находки Т. С. Теин (1979. С. 54) объясняет тем, что древние охотники о. Врангеля берегли гарпуны, так как их изготовление требовало особого мастерства. На наш взгляд, это свидетельствует скорее о временном сезонном характере врангелевской стоянки.

Определенное сходство по форме наконечников поворотных гарпунов с о. Врангеля и Древнекитобойной культуры с Аляски при разнице в размерах отмечают санкт-петербургские исследователи (Герасимов и др., 2003. С. 87).

По мнению Н. Н. Дикова (1979. С. 168), каменная индустрия врангелевской и древнейших палеоэскимосских культур Арктической Америки (северогренландской культуры Индепенденс и культуры Палисады II на м. Крузенштерна на Северо-Западной Аляске) имеет много общих черт. Ближайшие аналоги палеоэскимосской культуре на о. Врангеля наблюдаются в Древнекитобойной культуре на м. Крузенштерна, которая датируется 1450-1250 лет до н. э. (Ackerman, 1984. Р. 107). Однако отмечаются также ряд отличий и особенностей в каменном инвентаре между этими культурами: наконечники с боковыми выемками Древнекитобойной культуры имеют ланцетовидную форму и прямое основание, а врангелевские - листовидные с округлым основанием; скребки с черешками встречаются в обеих культурах, но на Чертовом Овраге их гораздо меньше (Герасимов и др., 2003).

Важным отличием врангелевского и гренландского комплексов является то, что в культуре Индепенденс I и II имеются ножевидные пластинки (Giddings, 1967. Fig. 107; Bandi, 1969. Fig. 64), а на стоянке Чертов Овраг о. Врангеля для изготовления каменных изделий используются отщепы, правильных ножевидных пластин в этом комплексе нет (Диков, 1977; 1979. С. 165-168; Теин, 1979, 1982). В материале стоянки Чертов Овраг имеются орудия со шлифовкой, в культуpe Индепенденс II шлифовка отсутствует. Мнения о наличии связей врангелевского комплекса с Индепенденс встречают возражения зарубежных археологов (Yamaura, 1980; Ackerman, 1984; МакГи, 1988).

Особенностью американских арктических стоянок Индепенденс II и Палисады II является наличие в этих комплексах наконечников с боковыми выемками (Bandi, 1969. Fig. 16, 64). По сравнению с ними врангелевские черешковые наконечники имеют грубую обработку и являются, вероятно, деградацией этого типа наконечников (Теин, 1979. Рис. 2).
Аналогии материалам культуры Индепенденс II имеются в Ипиутаке, Дорсете и кремневом комплексе Денби (Береговая, 1957. С. 32). Примечательно также сходство каменных изделий врангелевской культуры с «неолитическими камчатскими, североохотскими, а также древнеалеутскими» (Диков, 1979. С. 168). Об аналогиях каменного инвентаря с о. Врангеля и оквикской культуры говорили другие археологи (Борисковский, Хлобыстин, 1981. С. 317).

Таким образом, все это свидетельствует о том, что палеоэскимосская культура о. Врангеля относится, вероятно, к рубежу I тыс. до н. э. К этому можно добавить дорсетские параллели в каменном инвентаре врангелевской стоянки, которые отмечал Н. Н. Диков (1977. С. 128-129). Большинство радиоуглеродных датировок стоянки Чертов Овраг о. Врангеля относится к концу II - началу I тыс. до н. э. (Шило и др., 1979. C. 10). Р. Аккерман (Ackerman, 1998), учитывая поправку на резервуарный морской эффект, определял возраст стоянки $3000 \pm 155$ л. н.

На основе северогренландских параллелей Т. С. Теин (1979. С. 59) считал, что первые древние переселенцы прибыли из Северной Америки и Гренландии, а не с Азиатского материка. Вряд ли палеоэскимосские зверобои могли напрямую совершать такие длительные вояжи, минуя побережье Чукотки. Северное чукотское побережье, особенно его западная часть, изучены пока слабо. Вполне возможно, что палеоэскимосская культуpa, аналогичная врангелевской, будет обнаружена в последующих археологических исследованиях на северочукотском побережье. Отмечая сходство врангелевского и усть-бельского наконечников гарпунов, Т. С. Теин (1983. С. 59) предположил, что древние жители острова не только были связаны с Североамериканским континентом, но и имели культурные связи с обитателями материковой Чукотки. Наиболее верным, на наш взгляд, является его предположение, что древняя стоянка Чертов Овраг на о. Врангеля относится к древнейшему пласту палеоэскимосских племен - выходцев с Азиатского континента (Там же. С. 76). В то же время врангелевская палеоэскимосская культура тяготеет к тихоокеанским приморским культурам и, по-видимому, является частью древнейшего единого и широкого культурного пласта, на основе которого формировались многие приморские культуры Тихоокеанского Севера.

Почти все палеоэскимосские образцы, секвенированные в палеогенетических исследованиях последних лет, принадлежат к гаплогруппе D2a мтДНК. Генофонд палеоэскимосов складывался из двух компонентов - древнего палеосибирского, представленного геномом индивида из Дуванного Яра, и восточноазиатского (линия D2a мтДНК) (Гребенюк и др., 2019). Эта гаплогруппа также обнаружена у современных алеутов, 
чукчей, сирениковских эскимосов и индейцев надене, но при этом почти не фиксируется у современных инуитов. Предполагают, что образование протоэскимосоалеутской этнокультурной общности могло происходить на территории Чукотки в процессе культурной и биологической адаптации к экстремальным условиям Берингии переместившихся туда групп внутриконтинентального сибирского населения, а также южноазиатских и тихоокеанских мигрантов (Мовсесян, 2012).

Важнейшим открытием стала находка в 1997 г. еще одного палеоэскимосского поселения - Уненен, расположенного на южной оконечности Чукотского полуострова (Гусев, 2014). Находится оно на южной окраине современного с. Нунлигран. Раскопки проводились в $2007-$

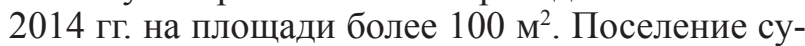
ществовало в период XV-XIII вв. до н. э. (Гусев, 2019). Каменный инвентарь этого памятника обнаруживает аналогии в культурах Пре-Дорсет и Дорсет Канадской Арктики, а также в Древнекитобойной культуре Аляски. Найденные поворотные наконечники гарпунов близки орудиям культуры Индепенденс II в Гренландии и стоянки Чертов Овраг на Чукотке. Зубчатые наконечники гарпунов алеутского типа, фаунистические остатки кита и ластоногих, уникальная находка моржового клыка с гравировкой сцен китовой охоты, ритуальные предметы и высокохудожественные изделия из клыка моржа, рога, дерева, китового уса и кожи подтверждают существование на Чукотке высокоразвитого морского зверобойного промысла уже во второй половине II тыс. до н. э. С. В. Гусев $(2007,2014)$ отнес поселение Уненен к Древнекитобойной культуре, предположив культурное и геохронологическое единство этого памятника со стоянкой Чертов Овраг, поселением на м. Крузенштерн и долахтинскими стоянками к югу от Анадырского залива. Он также полагал, что заселение участков побережий носителями, которые отнесены к палеоэскимосской традиции, происходило в результате климатических изменений и изменения береговой линии в результате подъема уровня моря (Гусев, 2007). Однако между комплексом Уненен и материалами Древнекитобойной культуры, а также «долахтинскими» памятниками и стоянки Чертов Овраг имеются типологические различия в инвентаре, что свидетельствует, скорее всего, о том, что все эти памятники могут иметь различное происхождение.

Д. Андерсон считает, что носители Древнекитобойной культуры вначале обитали в западной Арктике, формирование этой культуры происходило в районах Диомидовых островов или о. Св. Лаврентия и м. Принца Уэльского, Надежды, а также на северо-восточном побережье Азии (Giddings, Anderson, 1986. P. 332).

Еще одна приморская культура в Северном Приохотье - токаревская, по всей видимости, имеет определенные связи с палеоэскимосской традицией. Стоянки этой культуры расположены на побережье и островах в районе Тауйской губы и в устьях р. Окса, Ойра, на о. Завьялова, Недоразумения, Спафарьева, Талан, в бух. Токарева и на м. Восточный (Ольский). Возраст данной культуры определяется в рамках VIII в. до н. э. V в. н. э. (Лебединцев, 1990; Lebedintsev, 2000; Лебединцев, Кузьмин, 2010; Такасе и др., 2012). Предполагается, что в формировании этой культуры, наряду с северным (чукотско-камчатским приморским) и южным (приамурским континентальным) компонентами, участвовали неолитические культуры Колымы (Васильевский, 2001; Лебединцев, 2003). Высказывалось мнение, что приморская культура Северного Приохотья восходит своими корнями к палеоэско-алеутским прототипам (Арутюнов, Сергеев, 1975).

В археологических материалах токаревской культуры прослеживается влияние палеоэскимосской традиции. На уровне каменной индустрии это проявляется в отсутствии пластинчатой техники, характерной для континентальных культур, широкое использование отщепов и сколов для изготовления орудий, и в особенностях орудийного набора - наличии мелких изделий из халцедона: миниатюрных наконечников стрел, скребков овальной формы, вкладышей, мелких ножей листовидной формы (Лебединцев, 1990). На начальном этапе существования токаревской культуры отсутствовала керамика, очаги выложены из вертикально поставленных камней и имеют прямоугольную форму. Появление округлых жилищ с прямоугольными очагами, наряду с другими элементами, в токаревской культуре, возможно, связано с палеоалеутским влиянием (Лебединцев, 2007). Носители токаревской культуры обладали технологически развитым арсеналом для морского зверобойного промысла - поворотными наконечниками гарпунов традиции Дорсет с открытым гнездом, характерными зубчатыми наконечниками гарпунов, аналоги которых распространены на Юго-Западной Аляске и Алеутских островах (Lebedintsev, 1998). С. В. Гусев (2007. С. 61) отмечает сходство ряда элементов орнамента со стоянки Уненен с орнаментальными мотивами токаревкой культуры Северного Приохотья, что, на наш взгляд, не столь очевидно. На основе этих аналогий им также было сделано предположение о том, что очагом формирования палеоэскимосских культур Северо-Западного Берингоморья и Северо-Западной Аляски могли быть древние морзверобойные культуры Приохотья и Камчатки, хотя обоснованных доводов этому им не приводится.

Вопрос происхождения токаревской культуры связан с проблемой формирования на территории Северной Пацифики древних культур морских зверобоев, распространения гарпунной техники и приморского типа хозяйствования. По- 
явление примерно 3000-2800 л. н. на северном побережье Охотского моря высокотехнологичной культуры морских охотников, наряду с отсутствием археологических данных о ее постепенном формировании в этом регионе, позволяет предполагать генетические связи с палеоэскимосской традицией Чукотки, а также возможность независимой миграции палеоэско-алеутских групп из юго-западной Аляски и с Алеутских островов (Гребенюк и др., 2019). Палеогенетический анализ антропологических материалов стоянки Ольская показал, что индивиды токаревской культуры принадлежали к гаплогруппам D2a1 и G1b мтДНК и являлись потомками древней палеосибирской популяции, представленной геномом человека из Дуванного Яра (Sikora et al., 2019). Таким образом, древняя «палеоэскимосская» гаплогруппа D2a1 мтДНК была впервые обнаружена на северном побережье Охотского моря. Носители токаревской культуры также оказались ближайшими родственниками индивида палеоэскимосской культуры Саккак (4170-3600 кал. л. н.), обнаруженного в Западной Гренландии и являвшегося обладателем гаплогруппы D2a1 мтДНК и гаплогруппы Q-B143 Y-ДНК (Gilbert et al., 2008; Rasmussen et al., 2010). МтДНК, извлеченная из волос человека культуры Саккак, показала наибольшее сходство с мтДНК современного населения Алеутских островов и эскимосского поселения Сиреники на Чукотке (Gilbert et al., 2008). Ранее отмечалась выраженная связь генома носителя Саккак с геномами чукчей, коряков и нганасан (Rasmussen et al., 2010). Наиболее древним является эскимосо-алеутский субкластер D2a (возраст 10 тыс. лет) и чукотскоэскимосский А2 (возраст 8 тыс. лет) (Деренко, Малярчук, 2010. С. 311).

$\mathrm{B}$ филогенетическом отношении гаплотип D2a1, выявленный у индивидов токаревской культуры, такой же древний, как и у носителя культуры Саккак, из чего следует, что представители этой митохондриальной линии в Северном Приохотье и на Чукотке могли быть потомками предковой палеоэскимосской популяции, ранее прошедшей по этим территориям на Аляску, однако не исключается и возможность обратной миграции гаплогруппы D2a1 мтДНК. Интересно, что подгруппа Q-B143 Ү-ДНК, ассоциированная ранее с носителем культуры Саккак, присутствует в генофонде современных коряков, что в недавнем исследовании объясняется обратной миграцией палеоэскимосов (Grugni et al., 2019). В связи с этим можно привести результаты исследований «арктической» мутации гена СРТ1А в популяциях коренного населения Северо-Восточной Азии, возникновение которой напрямую связывается с популяциями арктических морских зверобоев (Малярчук и др., 2016). Наряду с высокими частотами «арктического» варианта гена СРТ1А в популяциях эскимосов, чукчей и коряков, эта же мутация была обнаружена с частотой $10.3 \%$ у нанайцев северо-восточного Китая ( $\mathrm{Li}$ et al., 2018). Присутствие «арктической» мутации у нанайцев может объясняться дальними миграциями палеоэско-алеутских групп или более поздними миграциями носителей токаревской или древнекорякской культуры на юг Дальнего Востока.

Таким образом, токаревская культура Северного Приохотья (800 г. до н. э. -500 г. н. э.) культурно-хронологически и генетически может быть отнесена к палеоэскимосскому кругу археологических культур, с середины III тыс. до н. э. распространившихся на Аляске, в Арктической Канаде и Гренландии. Все палеоэскимосские культуры отличались определенным своеобразием и существовали на огромной территории. Синхронно токаревской культуре в Канадской Арктике период 800-500 гг. до н. э. рассматривается как переходный от Пре-Дорсета к Дорсету, период 500-300 гг. до н. э. - Ранний Дорсет, период 300 г. до н. э - 500 г. н. э. - Средний Дорсет. На западном побережье Аляски развиваются культуры Чорис (между 750-400 гг. до н. э.) и Нортон (с 500 г. до н. э.) (Dumond, 2016; Milne, Park, 2016; Darwent, Darwent, 2016; Grønnow, 2016). Возможно также, что происхождение токаревской культуры связано с миграцией палеоэскоалеутов с ЮгоЗападной Аляски и Алеутских островов. По всей видимости, токаревская культура сформировалась на основе палеоэско-алеутских и внутриконтинентальных колымских групп, а также нижнеамурского культурного компонента на поздних этапах существования (Лебединцев, 2019).

Палеоэскимосское или палеоэскоалеутское влияние на культуры Охотского побережья осуществлялось в результате культурных контактов, возможно, через культуры Северной Камчатки (Лебединцев, 1998). Вполне возможно, что какое-то эско-алеутское население небольшими группами могло достигнуть севера Камчатки. Северная Камчатка была, вероятно, местом оживленных культурных контактов между древним населением Камчатки, северного побережья Охотского моря и Чукотки. В дальнейшем палеоэскимосская традиция распространилась на Северное Приохотье, в результате чего началось формирование токаревской культуры.

В Приморье была выделена и исследована бойсманская неолитическая культура, которая существовала в период начала V - середины III тыс. до н. э. (Попов и др., 1997). Д. Л. Бродянский (2007) считает эту культуру протоберингийской, а бойсманцев - арктическими монголоидами, вероятными предками современных жителей Берингии (чукчей, коряков, ительменов, эскимосов). Он также полагает, что именно бойсманцы заселили Берингию и их путь на север длился 1.5-2 тыс. лет, который они прошли морем. Ан- 
тропологи, изучавшие материалы бойсманских могильников, сделали заключение, что «антропометрические и антропоскопические признаки черепов из Бойсмана II образуют комбинацию, наиболее близкую к древним и современным сериям арктической расы. Максимальное сходство обнаруживается с оленными чукчами» (Попов и др., 1997. С. 79). Доводы, приведенные в доказательство, вызывают критику и сомнительны. Однако степень сходства далеко не всегда соответствует степени родства, что отмечал Г. Ф. Дебец (1986. С. 22). Причем сходство фиксируется с наиболее поздним этническим образованием - с оленными чукчами, формирование которых связано с возникновением кочевого оленеводства в первой половине II тыс. н. э. (Лебединцев, 2013). Но самое главное, отсутствуют особые причины для миграции бойсманцев в арктические районы. Бойсманцы, вытесненные на север земледельцами-зайсановцами, скорее всего, растворились в среде обитателей Приамурья. Арктические черты у бойсманцев не могли сформироваться в Приморье. Арктический адаптивный комплекс может сформироваться только в области экстремальных условий существования человека в высоких широтах Севера (Первоначальное..., 2014. С. 408). Сам чукотский тип представляет собой самостоятельный, особый тип, отличный от байкальского и других вариантов североазиатской расы (Беневоленская, 1988). В прошлом он составлял основу морфологии предков чукчей и уже имелся у населения Усть-Бельской культуры (II - начало I тыс. до н. э.). В отношении морского зверобойного промысла бойсманцы в период голоценового оптимума могли охотиться на морских животных с помощью гарпунов с неповоротными зубчатыми наконечниками на мелководных лагунах (Попов, 2001). Вряд ли такие несовершенные поворотные наконечники гарпунов бойсманской культуры могли использоваться для охоты на китов и крупных сивучей (Там же. Рис. 11). Данные химического анализа костных останков людей из бойсманских могильников показали, что большая часть пищи имела морское происхождение. В то же время предполагается, что основу диеты бойсманцев составляли морские млекопитающие. Исходя из этого, сделан вывод о том, что большинство наконечников гарпунов использовались для зверобойного промысла. Однако следует отметить, что рыба, добываемая в лагунах, тоже имеет морское происхождение. Фигурки ластоногих, приведенные в доказательство охоты на морских животных, вызывают сомнения (Бродянский,1998. Рис. 3). Впоследствии все же возобладало другое мнение, что неолитические обитатели предпочитали прибрежное рыболовство на мелководье и в лагунах, для чего применяли также гарпуны (Попов и др., 2011).
Таким образом, можно представить следующий сценарий развития ранней приморской адаптации и появления палеоэскимосской традиции на Северо-Востоке России. Миграция предков палеоэскимосов на Американский континент произошла в период 7500-5500 кал. л. н. С III тыс. до н. э. палеоэскимосская традиция распространяется в Арктической Канаде и Гренландии. Основой развития палеоэскимосских культур стала «арктическая традиция малых орудий» («Arctic Small Tool tradition»). Основные черты палеэскимосской традиции появляются уже на раннем этапе (культуры Пре-Дорсет, Индепенденс I, Саккак). В генофонде палеоэскимосов выявлен геном древнего палеосибирского (индивид из Дуванного Яра, гаплогруппа G1b мтДНК) и восточноазиатского населения (гаплогруппа D2a), близкого индивидам из пещеры Чертовы Ворота в Приморье и захоронения китойской культуры в Забайкалье. Появление палеоэскимосской традиции на крайнем СевероВостоке Азии связано с экспансией палеоэскимосских групп Канадской Арктики и Гренландии в район Берингоморья примерно 3500 кал. л. н. К палеоэскимосскому периоду относятся временная сезонная стоянка Чертов Овраг на о. Врангеля и поселение Уненен, расположенное на южной оконечности Чукотского полуострова в районе с. Нунлигран. Токаревская культура может быть отнесена к кругу палеоэскимосских культур или связана с палеоэскоалеутской миграцией из ЮгоЗападной Аляски и с Алеутских островов.

Исследование выполнено при финансовой поддержке РФФИ в рамках научного проекта № 19-09-00144 «Древние приморские культуры Северного Приохотья и Камчатки в контексте освоения человеком Северной Пацифики» (руководитель А. И. Лебединцев).

\section{ЛИТЕРАТУРА}

Александров С. А., Арутюнов А. В., Бродянский Д. Л. Палеометалл северо-западной части Тихого океана. Владивосток : Изд-во Дальневост. ун-та, 1982. 104 с.

Арутюнов С. А., Сергеев Д. А. Проблемы этнической истории Берингоморья. М. : Наука, 1975. 240 с.

Беневоленская Ю. Д. Арктическая раса (проблема формирования) // Расы и народы. М. : Наука, 1988 Вып. 18. С. 75-91.

Береговая Н. А. Находки доэскимосских поселений на Аляске и в прилегающих областях, по работам 1945-1954 гг.: (К вопросу о заселении Америки) // Сов. этнография. 1957. № 2. С. 15-39.

Борисковский П. И., Хлобыстин Л. П. [Рецензия] // Там же. 1981. № 1. С. 314-319. Рец. на кн.: Диков Н. Н. 1) Археологические памятники Камчатки, Чукотки и Верхней Колымы. М., 1977. 391 с.; 2) Древние культуры Северо-Восточной Азии. М., 1979. 352 с.

Бродянский Д. Л. Бойсманские фигурки // Мир древних образов на Дальнем Востоке : Девяностолетию светлой памяти А. П. Окладникова посвящается. Владивосток : ДВГУ, 1998. С. 92-101 (Тихоокеанская археология; вып. 10). 
Бродянский Д. Л. Протоберингийская культура в Приморье // Этноистория и археология Северной Евразии: теория, методология и практика исследования : сб. науч. тр. Иркутск; Эдмонтон : Изд-во ИрГТУ, 2007. C. 30-32.

Васильевский Р. С. Генезис и взаимодействие культур Северной Пасифики // Археология, этнография и антропология Евразии. 2001. № 3. С. 31-38.

Герасимов Д. В., Гиря Е. Ю., Тихонов А. Н. Поселение Чертов Овраг на острове Врангеля - вопросы культурной атрибуции и перспективы исследования // Естественная история российской восточной Арктики в плейстоцене и голоцене : сб. статей. М. : ГЕОС, 2003. С. 85-88.

ГребенюкП. С., Федорченко А. Ю., Лебединиев А. И., Малярчук Б. А. Древние культуры крайнего СевероВостока Азии и этногенетические реконструкции // Том. журн. лингвист. и антропол. исследований. 2019. № 2. C. 110-136.

Гусев С. В. Древнекитобойная культура и синхронные культуры Северного Берингоморья (конец II - начало I тыс. до н. э.) // Приоткрывая завесу тысячелетий: к 80-летию Жанны Васильевны Андреевой : сб. науч. тр. / отв. ред. Н. А. Клюев, Ю. Е. Вострецов. Владивосток : ООО «Рея», 2010. С. 191-209.

Гусев С. В. Древнекитобойная культура Чукотки и Аляски // Этноистория и археология Северной Евразии: теория, методология и практика исследования : сб. науч. тр. Иркутск; Эдмонтон : Изд-во ИрГТУ, 2007. С. 59-62.

Гусев С. В. Раскопки поселения Уненен на Восточной Чукотке (древнекитобойная культура) в $2007-$ 2014 гг. // Археология Арктики. Екатеринбург : Деловая пресса, 2014. Вып. 2. С. 205-212.

Гусев С. В. Сакральные предметы поселения Уненен (древнекитобойная культура, XV-XIII вв. до н. э.) / V Северный археол. конгресс : тез. докл. 1114 дек. 2019, Ханты-Мансийск. Екатеринбург ; ХантыМансийск : ООО Универсальная типография «АльфаПринт», 2019. С. 366-368.

Дебеи Г. Ф. Палеоантропология древних эскимосов (Ипиутак, Тигара) // Этнические связи народов Севера Азии и Америки по данным антропологии. М. : Наука, 1986. С. 6-149.

Деренко М. В., Малярчук Б. А. Молекулярная филогеография населения Северной Евразии по данным об изменчивости митохондриальной ДНК. Магадан : СВНЦ ДВО РАН, 2010. 376 с.

Диков Н. Н. Азия на стыке с Америкой в древности: Каменный век Чукотского полуострова. СПб. : Наука, 1993. 304 с.

Диков Н. Н. Древние культуры Северо-Восточной Азии: Азия на стыке с Америкой в древности. М. : Наука, 1979. 352 с.

Диков Н. Н. Открытие палеоэскимосской культуры на острове Врангеля // Краевед. записки. Магадан : Кн. изд-во, 1977. Вып. 11. С. 127-130.

Лебединцев А. И. Древние приморские культуры Северо-Западного Приохотья. Л. : Наука, 1990. 260 с.

Лебединцев А. И. К проблеме происхождения древних приморских культур Севера Дальнего Востока // Археология, этнография и антропология Евразии. 2003. № 2. С. 87-93.

Лебединцев А. И. Охота на оленей и проблема происхождения оленеводства на севере Дальнего Востока // Древние культуры Монголии и Байкальской Си- бири : материалы IV Междунар. науч. конф.: в 2 ч. Чита, 13-19 сент. 2013 г. Чита, 2013. Ч. 2. С. 222-228.

Лебединцев А. И. Очаги в древних приморских культурах Севера Дальнего Востока // Чтения памяти академика К. В. Симакова : тез. докл. Всерос. науч. конф. (Магадан, 27-29 нояб. 2007 г.). Магадан : СВНЦ ДВО РАН, 2007. С. 242-243.

Лебединцев А. И. Приморские культуры Охотоморья: эскимосско-алеутское влияние / V Северный археол. конгресс : тез. докл., 11-14 дек. 2019, ХантыМансийск. Екатеринбург ; Ханты-Мансийск : ООО Универсальная типография «Альфа-Принт», 2019. C. $175-177$.

Лебединиеев А. И. Эскимосо-алеутское влияние на формирование и развитие приморских культур в Северном Приохотье // Историко-культурные связи между коренным населением тихоокеанского побережья Северо-Западной Америки и Северо-Восточной Азии : К 100-летию Джезуповской северотихоокеанской экспедиции : Материалы междунар. конф. (Владивосток, 1-5 апр. 1998 г.). Владивосток, 1998. С. 121-127.

Лебединцев А. И., Кузьмин Я. В. Радиоуглеродное датирование археологических памятников Северного Приохотья (Дальний Восток России) // VI Диковские чтения : Материалы науч.-практ. конф., посвящ. 85-летию со дня рожд. Н. Н. Дикова и 50-летию образования СВКНИИ ДВО РАН. Магадан : СВКНИИ ДВО РАН, 2010. С. 116-120.

МакГи Р. Происхождение эскимосов: возможна ли альтернативная гипотеза? // Сов. этнография. 1988. № 3. C. 110-118.

Малярчук Б. А., Деренко М. В., Денисова Г. А., Литвинов $A$. Н. Распространенность арктического варианта гена СРТ1А в популяциях коренного населения Сибири // Вавиловский журнал генетики и селекции. 2016. T. 20, № 5. С. 571-575.

Мовсесян А. А. Палеофенетический анализ современного и древнего населения Чукотки // Археология, этнография и антропология Евразии. 2012. № 3. C. $130-137$.

Первоначальное заселение Арктики человеком в условиях меняющейся среды : атлас-монография / отв. ред. В. М. Котляков, А. А. Величко, С. А. Васильев. М. : ГЕОС, 2014. 519 с.

Питулько В. В. Голоценовый каменный век СевероВосточной Азии // Естественная история российской восточной Арктики в плейстоцене и голоцене : сб. статей. М. : ГЕОС, 2003. С. 99-151.

Питулько В. В. Жоховская стоянка. СПб. : Дмитрий Буланин, 1998. 186 с.

Питулько В. В. Морские адаптации на СевероВостоке Азии // Диковские чтения : Материалы науч.практ. конф., посвящ. 75-летию со дня рожд. чл.-корр. РАН Н. Н. Дикова. Магадан : СВКНИИ ДВО РАН, 2001. С. 64-71.

Питулько $B . \quad B$. Хозяйственно-культурный тип поздненеолитического населения Чукотки // Древние памятники Севера Дальнего Востока. Магадан : СВКНИИ, 1990. С. 74-79.

Попов А. Н. Комплекс промысловых орудий из кости, рога и клыка бойсманской археологической культуры // Произведения искусства и другие древности из памятников Тихоокеанского региона - от Китая до Гондураса. Владивосток, 2001. С. 36-54. 
Попов А. Н., Чикишева Т. А., Шпакова Е. Г. Бойсманская археологическая культура Южного Приморья (по материалам многослойного памятника Бойсмана II). Новосибирск : ИИАЭт СО РАН, 1997. 96 с.

Попов А. Н., Раков В. А., Лазин Б. В. Древнее морское рыболовство в Южном Приморье (по материалам раковинных куч неолита и раннего железного века) // Вестник НГУ. Сер.: История, филология. 2011. Т. 10. Вып. 7: Археология и этнография. С. 140-145.

Такасе К., Лебединцев А. И., Пташинский А. В. Новые радиоуглеродные даты для Северного Приохотья и северо-восточного побережья Камчатки // VII Диковские чтения : Материалы науч.-практ. конф., посвящ. 80летию промышленного освоения Колымы и 100-ле-тию открытия морского торгового пути в Восточную Арктику. Магадан : СВКНИИ ДВО РАН, 2012. С. 139-143.

Теин T. C. Археологические исследования на о. Врангеля // Новые археологические памятники Севера Дальнего Востока (по данным СВАКАЭ). Магадан : СВКНИИ ДВНЦ АН СССР, 1979. С. 53-63.

Теин T. С. Раскопки на о-ве Врангеля // Краевед. записки. Магадан : Кн. изд-во, 1982. Вып. 12. С. 124-129.

Теин T. C. Тайна Чертова Оврага. Магадан : Кн. изд-во, 1983.94 с.

Шило Н. А., Диков Н. Н., Ложкин А. В., Орехов А. А., Теин T. $C$. Новые радиоуглеродные датировки археологических памятников Северо-Восточной Азии // Новые археологические памятники Севера Дальнего Востока (по данным СВАКАЭ). Магадан : СВКНИИ ДВНЦ АН СССР, 1979. С. 9-11.

Ackerman $R$. E. Early maritime traditions in the Bering, Chukchi, and East Siberian Seas // Arctic Anthropology. 1998. Vol. 35, No. 1. P. 247-262.

Ackerman R. E. Prehistory of the Asian Eskimo zone // Handbook of North American Indians. Washington, 1984. Vol 5. P. 106-118.

Ackerman R. E. Settlements and sea mammal hunting in the Bering-Chukchi Sea region // Arctic Anthropology. 1988. Vol. 25, No. 1. P. 52-79.

Bandi H.-G. Eskimo prehistory. College : University of Alaska Press, 1969. 226 p.

Berge A. Eskimo-Aleut // Oxford Research Encyclopedia of Linguistics. Amsterdam : Elsevier, 2016. P. 219-223.

Darwent C. M., Darwent J. The enigmatic Choris and Old Whaling "cultures" of the Western Arctic // The Oxford Handbook of the Prehistoric Arctic / eds. T. M. Friesen, O. K. Mason. Oxford : Oxford University Press, 2016. P. 371-394.

Dikov $N$. N. The oldest sea mammal hunters of Wrangel Island // Arctic Anthropology. 1988. Vol. 25, No. 1. P. 80-93.

Dumond D. E. Norton hunters and fisherfolk // The Oxford Handbook of the Prehistoric Arctic / eds. T. M. Friesen, O. K. Mason. Oxford : Oxford University Press, 2016. P. 395-416.

Encyclopedia of Prehistory: Vol. 2. Arctic and Subarctic. Dordrecht : Kluwer Academic Publishers, 2001. 239 p.

Fitzhugh W. W. Paleo-Eskimo cultures of Greenland // Handbook of North American Indians. Washington, 1984. Vol. 5. P. 528-539.

Fortescue M. Language Relations across Bering Strait: Reappraising the Archaeological and Linguistic Evidence. London : Cassell Academic, 1998. 316 p.

Friesen M. Pan-Arctic population movements: The early Paleo-Inuit and Thule Inuit migrations // The Ox- ford Handbook of the Prehistoric Arctic. Oxford, 2016. P. 673-691.

Giddings J. L. Ancient men of the Arctic. New York : Knopf, 1967. 410 p.

Giddings J. L., Anderson D. D. Beach Ridge archaeology of Cape Krusenstern: Eskimo and Pre-Eskimo settlements around Kotzebue Sound, Alaska. Washington : Nationall Park Service, U. S. Department of Interior, 1986. $386 \mathrm{p}$.

Gilbert M. T., Kivisild T., Grønnow B. Andersen P. K., Metspalu E., Reidla M., Tamm E., Axelsson E., Götherström A., Campos P. F., Rasmussen M., Metspalu M., Higham T. F., Schwenninger J. L., Nathan R., De Hoog C. J., Koch A., Møller L. N., Andreasen C., Meldgaard M., Villems R., Bendixen C., Willerslev E. Paleo-Eskimo mtDNA genome reveals matrilineal discontinuity in Greenland // Science. 2008. Vol. 320. P. 1787-1789.

Giddings $J$. L. The archaeology of Cape Denbigh. Providence, Rhode Island : Brown University Press, 1964. $331 \mathrm{p}$.

Grønnow B. Independence I and Saqqaq: The first Greenlanders // The Oxford Handbook of the Prehistoric Arctic / eds. T. M. Friesen, O. K. Mason. Oxford : Oxford University Press, 2016. P. 712-734.

Grugni V., Raveane A., Ongaro L., Battaglia V., Trombetta B., Colombo G., Capodiferro M. R., Olivieri A., Achilli A., Perego U. A., Motta J., Tribaldos M., Woodward S. R., Ferretti L., Cruciani F., Torroni A., Semino O. Analysis of the human Y-chromosome haplogroup Q characterizes ancient population movements in Eurasia and the Americas // BMC Biology. 2019. Vol. 17 (1). P. 3.

Lebedintsev A. I. Early maritime cultures of Northwestern Priokhot'e. Anchorage : NPS, 2000. 288 p.

Lebedintsev A. I. Maritime cultures of the north coast of the Sea of Okhotsk // Arctic Anthropology. 1998. Vol. 35 (1). P. 296-320.

Li Q., Dong K., Xu L. Jia X., Wu J., Sun W., Zhang $X$., $F u S$. The distribution of three candidate cold-resistant SNPs in six minorities in North China // BMC Genomics. 2018. Vol. 19. Iss. 134.

McGhee R. The Paleoeskimo occupations at Port Refuge, High Arctic Canada // Archaeological Survey of Canada, Mercury Series. Paper 92. Ottawa : National Museum of Man, 1979. $176 \mathrm{p}$.

Milne S. B., Park R. Pre-Dorset culture // The Oxford Handbook of the Prehistoric Arctic. Oxford : University Press, 2016. P. 693-711.

Powers W. R., Richard H. J. Human biogeography and climate change in Siberia and Arctic North America in the fourth and fifth millennia BP // Philosophical Transactions of the Royal Society of London, Series A, Mathematical and Physical Sciences. 1990. Vol. 330, No. 1615. P. 665-670.

Rasmussen M., Li Y., Lindgreen S., Pedersen J. S., Albrechtsen A., Moltke I., Metspalu M., Metspalu E., Kivisild T., Gupta R., Bertalan M., Nielsen K., Gilbert M. T., Wang Y., Raghavan M., Campos P. F., Kamp H. M., Wilson A. S., Gledhill A., Tridico S., Bunce M., Lorenzen E. D., Binladen J., Guo X., Zhao J., Zhang X., Zhang H., Li Z., Chen M., Orlando L., Kristiansen K., Bak M., Tommerup N., Bendixen C., Pierre T. L., Grønnow B., Meldgaard M., Andreasen C., Fedorova S. A., Osipova L. P., Higham T. F., Ramsey C. B., Hansen T. V., Nielsen F. C., Crawford M. H., Brunak S., Sicheritz-Pontén T., Villems R., Nielsen R., Krogh A., Wang J., Willerslev E. Ancient human genome 
sequence of an extinct Paleo-Eskimo // Nature. 2010. Vol. 463. P. 757-762.

Sikora M., Pitulko V., Sousa V., Allentoft M. E., Vinner L., Rasmussen S., Margaryan A., De Barros Damgaard P., de la Fuente C., Renaud G., Yang M.A., Fu Q., Dupanloup I., Giampoudakis K., Nogués-Bravo D., Rahbek C., Kroonen G., PeyrotM., Mc. Coll H., Vasi-lyevS. V., Veselovskaya E., Gerasimova M., Pavlova E. Y., Chasnyk V. G., Nikolskiy P. A., Gromov A. V., Khartanovich V. I., Moiseyev V., Grebenyuk P. S., Fedorchenko A. Y., Lebedintsev A. I., Slobodin S. B., Malyarchuk B. A., Martiniano R., Meldgaard M., Arppe L., Palo J. U., Sundell T., Mannermaa K., Putkonen M., Alexandersen V., Primeau C., Baimukhanov N., Malhi R. S., Sjögren
K. G., Kristiansen K., Wessman A., Sajantila A., Lahr M. M., Durbin R., Nielsen R., Meltzer D. J., Excoffier L., Willerslev E. The population history of Northeastern Siberia since the Pleistocene // Nature. 2019. Vol. 570. P. 182-188.

Sørensen M. The archaeology of Old Nuulliit: Eigil Knuth's Investigations in the Thule region, North Greenland, 1952-1990. Copenhahen : Museum Tusculanum Press (Monographs on Greenland, vol. 349), 2010. 146 p.

The Oxford Handbook of the prehistoric Arctic. NY ; Oxford University Press, 2016. 988 p.

Yamaura K. On the relationships of the toggle harpoon heads discovered from the north-western shore of the Pacific // Material Culture. 1980. No. 35. P. 1-19.

Поступила в редакцию 11.01.2020 2.

Поступила после доработки 17.01.2020 2.

\title{
THE PROBLEM OF THE PALEO-ESKIMO CULTURES ORIGIN AND THE EMERGENCE OF THEIR SITES IN THE NORTH-EAST OF RUSSIA
}

\section{A. I. Lebedintsev}

\begin{abstract}
North-East Interdisciplinary Scientific Research Institute n. a. N. A. Shilo, FEB RAS, Magadan
\end{abstract}
The article discusses the Paleoeskimos origin problem. Paleo-Eskimos' ancestors migrated to the American continent 7500 and $5500 \mathrm{ca}$. yrs. ago. Paleo-Eskimo cultures developed on the base of the "Arctic Small Tool tradition". The genome of the ancient Paleosiberian (an individual from Duvani Yar, Niznekolymsky District, Yakutia) and the East Asian population, close to individuals from the Chertovy Vorota cave in Primorye and the burial place of the Kitoy culture in Transbaikalia, were revealed in the genome pool of the Paleo-Eskimos. The main features of the Paleo-Eskimo tradition appear at an early stage (Pre-Dorset, Independence I, Saqqaq cultures). The emergence of the Paleo-Eskimo tradition in the Far North-East of Asia is associated with the expansion of the PaleoEskimo groups from the Canadian Arctic and Greenland to the Bering Sea region approximately 3500 ca. yrs. ago. The Paleo-Eskimo period includes the temporary seasonal Chertov Ovrag site on Wrangel Island and the Unenen settlement, located on the southern tip of the Chukchi Peninsula. The Tokarevskaya culture can be referred to Paleo-Eskimo cultures or associated with the PaleoEsko-Aleutian migration from Southwest Alaska and the Aleutian Islands.

Keywords: origin of Paleo-Eskimo cultures, sites of the Paleo-Eskimo tradition, North-East of Russia.

\section{REFERENCES}

Ackerman, R. E., 1984, Prehistory of the Asian Eskimo Zone, Handbook of North American Indians, Washington, 5, 106-118.

Ackerman, R. E., 1988, Settlements and Sea Mammal Hunting in the Bering-Chukchi Sea Region, Arctic Anthropology, 25, 1, 52-79.

Ackerman, R. E., 1998, Early Maritime Traditions in the Bering, Chukchi, and East Siberian Seas, Ibid., 35, 1, 247-262.

Aleksandrov, S. A.; Arutyunov, A. V.; Brodyansky, D. L., 1982, Paleo-metal of the Northwest Pacific Ocean, Vladivostok, Dalnevostochny Universitet [In Russian].

Arutyunov, S. A.; Sergeev, D. A., 1975, Problems of the Ethnic History of the Bering Sea, Moscow, Nauka [In Russian].

Bandi, H.-G., 1969, Eskimo Prehistory, College, University of Alaska Press.

Benevolenskaya, Yu. D., 1988, Arctic Race (the Problem of Formation), Races and Peoples, Moscow, Nauka, 18, 75-91 [In Russian].
Beregovaya, N. A., 1957, Findings of Pre-Eskimo Settlements in Alaska and Adjacent Areas, the Works of 19451954: (On the Settlement of America Issue), Sovietskaya Ethnografiya, 2, 15-39 [In Russian].

Berge, A., 2016, Eskimo-Aleut, Oxford Research Encyclopedia of Linguistics, Amsterdam, Elsevier, 219-223.

Boriskovsky, P. I.; Khlobystin, L. P., 1981, Review of the Book: Dikov N. N. 1) Archaeological Sites of Kamchatka, Chukotka, and Upper Kolyma. Moscow, 1977; 2) Ancient Cultures of Northeast Asia. Moscow, 1979, Sovietskaya Etnografiya, 1, 314-319 [In Russian].

Brodyansky, D. L., 1998, Boysman Figures, The World of Ancient Images in the Far East: Dedicated to the Ninth Century of A. P. Okladnikov's Blessed Memory, Vladivostok, 92-101 [In Russian].

Brodyansky, D. L., 2007, Proto-Beringian Culture in Primorye, Ethnohistory and Archeology of Northern Eurasia: Theory, Methodology, and Research Practice: Collection of Scientific Papers, Irkutsk, Edmonton, ISTU, 3032 [In Russian]. 
Darwent, C. M.; Darwent, J., 2016, The Enigmatic Choris and Old Whaling "Cultures" of the Western Arctic, Ibid., 371-394.

Debets, G. F., 1986, Paleoanthropology of Ancient Eskimos (Ipiutak, Tigara), Ethnic Relations of the Peoples of the North of Asia and America, by Anthropological Data, Moscow, Nauka, 6-149 [In Russian].

Derenko, M. V.; Malyarchuk, B. A., 2010, Molecular Phylogeography of the Northern Eurasia's Population by the Data on the Mitochondrial DNA Variability, Magadan, NESC FEB RAS [In Russian].

Dikov, N. N., 1977, Discovery of the Paleo-Eskimo Culture on Wrangel Island, Krayevedcheskiye Zapiski, Magadan, 11, 127-130 [In Russian].

Dikov, N. N., 1979, Ancient Cultures of North-East Asia: Asia at the Junction with America in Antiquity, Moscow, Nauka [In Russian].

Dikov, N. N., 1988, The Oldest Sea Mammal Hunters of Wrangel Island, Arctic Anthropology, 25 (1), 80-93 [In Russian].

Dikov, N. N., 1993, Asia at the Junction with America in Antiquity: The Stone Age of the Chukchi Peninsula, St. Petersburg, Nauka [In Russian].

Dumond, D. E., 2016, Norton Hunters and Fisherfolk, The Oxford Handbook of the Prehistoric Arctic, Eds. T. M. Friesen, O. K. Mason, Oxford, Oxford University Press, 395-416.

Encyclopedia of Prehistory, 2001, Arctic and Subarctic, Vol. 2, Dordrecht, Kluwer Academic Publishers.

Fitzhugh, $W . W .$, 1984, Paleo-Eskimo Cultures of Greenland, Handbook of North American Indians, Washington, 5, 528-539.

Fortescue, M., 1998, Language Rerlations across Bering Strait: Reappraising the Archaeological and Linguistic Evidence, London, Cassell Academic.

Friesen, M., 2016, Pan-Arctic Population Movements: The Early Paleo-Inuit and Thule Inuit Migrations, The Oxford Handbook of the Prehistoric Arctic, Oxford, 673-691.

Gerasimov, D. V.; Girya, E. Yu.; Tikhonov, A. N., 2003, The Chyortov Ovrag Settlement on Wrangel Island - Issues of Cultural Attribution and Research Prospects, Natural History of Russia's East Arctic in the Pleistocene and Holocene, Moscow, GEOS, 85-88 [In Russian].

Giddings, J. L., 1964, The Archaeology of Cape Denbigh. Providence, Rhode Island, Brown University Press.

Giddings, J. L., 1967, Ancient Men of the Arctic, New York, Knopf Publisher.

Giddings, J. L.; Anderson, D. D., 1986, Beach Ridge Archaeology of Cape Krusenstern: Eskimo and Pre-Eskimo Settlements Around Kotzebue Sound, Alaska, Publications in Archaeology, 20, Washington, D. C., National Park Service, U. S. Department of Interior.

Gilbert, M. T.; Kivisild, T.; Grønnow, B.; Andersen, P. K.; Metspalu, E.; Reidla, M.; Tamm, E.; Axelsson, E.; Götherström, A.; Campos, P. F.; Rasmussen, M.; Metspalu, M.; Higham, T. F.; Schwenninger, J. L.; Nathan, R.; De Hoog, C. J.; Koch, A.; Møller, L. N.; Andreasen, C.; Meldgaard, M.; Villems, R.; Bendixen, C.; Willerslev, E., 2008, Paleo-Eskimo mtDNA Genome Reveals Matrilineal Discontinuity in Greenland, Science, 320, 1787-1789.

Grebenyuk, P. S., 2019, Origin of the Paleo-Eskimos and the Paleo-Eskimo Tradition, $V$ Northern Archeological Congress, Abstracts, December 11-14, 2019, KhantyMansiysk, Yekaterinburg - Khanty-Mansiysk, Alfa-Print, 74-76 [In Russian].
Grugni, V.; Raveane, A.; Ongaro, L.; Battaglia, V.; Trombetta, B.; Colombo, G.; Capodiferro, M. R.; Olivieri, A.; Achilli, A.; Perego, U. A.; Motta, J.; Tribaldos, M.; Woodward, S. R.; Ferretti, L.; Cruciani, F.; Torroni, A.; Semino, O., 2019, Analysis of the Human Y-chromosome Haplogroup Q Characterizes Ancient Population Movements in Eurasia and the Americas, BMC Biology, 17 (1), 3.

Gusev, S. V., 2007, Old Whaling Culture of Chukotka and Alaska, Ethnohistory and Archeology of Northern Eurasia: Theory, Methodology, and Research Practice, Irkutsk, Edmonton, ISTU, 59-62 [In Russian].

Gusev, S. V., 2010, Old Whaling Culture and Synchronous Cultures of the North Bering Sea (Late $2^{\text {nd }}-$ Early $1^{\text {st }}$ Millennium B. C.), Lifting the Veil Millennia of : to the $80^{\text {th }}$ Anniversary of Zhanna Vasilyevna Andreeva, Vladivostok, Reya, 191-209 [In Russian].

Gusev, S. V., 2014, Excavations of the Unenen Settlement in East Chukotka (Old Whaling Culture) in 20072014, Archeology of the Arctic, Yekaterinburg, Business Press, 2, 205-212 [In Russian].

Gusev, S. V., 2019, Sacred Objects from the Unenen Settlement (Old Whaling Culture, $15^{\text {th }}-13^{\text {th }}$ Centuries B. C.), V Northern Archeological Congress, Abstracts, December 11-14, 2019, Khanty-Mansiysk, Yekaterinburg - Khanty-Mansiysk, Alfa-Print, 366-368 [In Russian].

Grønnow, B., 2016, Independence I and Saqqaq: The First Greenlanders, The Oxford Handbook of the Prehistoric Arctic, Eds.T. M. Friesen, O. K. Mason, Oxford, Oxford University Press, 712-734.

Initial Human Settlement of the Arctic in a Changing Environment: Atlas Monograph, 2014, Eds. V. M. Kotlyakov, A. A. Velichko, S. A. Vasilyev, Moscow, GEOS [In Russian].

Lebedintsev, A. I., 1990, Ancient Coastal Cultures of the Northwest Priokhotye, Leningrad, Nauka [In Russian].

Lebedintsev, A. I., 1998, Eskimo-Aleutian Influence on the Formation and Development of Coastal Cultures in the Northern Priokhotye, Historical and Cultural Ties between the Indigenous People of the Pacific Coast of Northwest America and North-East Asia : On the 100 ${ }^{\text {th }}$ Anniversary of the Jesup's North Pacific Expedition: Materials of the International Conference, Vladivostok, April 1-5, 1998, Vladivostok, 121-127 [In Russian].

Lebedintsev, A. I., 1998, Maritime Cultures of the North Coast of the Sea of Okhotsk, Arctic Anthropology, 35 (1), 296-320.

Lebedintsev, A. I., 2000, Early Maritime Cultures of Northwestern Priokhot'e, Anchorage, Nat. Park Service.

Lebedintsev, A. I., 2003, On the Problem of the Origin of Ancient Coastal Cultures of the North of the Far East, Archaeology, Ethnology \& Anthropology of Eurasia, 2, 8793 [In Russian].

Lebedintsev, A. I., 2007, Hearths in Early Maritime Cultures of Northern Far East, Conference Dedicated to the Memory of Academician K. V. Simakov, Proceedings (Magadan, November 27-29, 2007), Magadan, NEISRI FEB RAS, 242-243 [In Russian].

Lebedintsev, A. I., 2013, Reindeer Hunting and the Problem of the Reindeer Herding Origin in the North of the Far East, Ancient Cultures of Mongolia and Baikal Siberia, Materials of the IV International Scientific Conference, Chita, September 13-19, 2013, Chita, Book 2, 222228 [In Russian].

Lebedintsev, A I., 2019, Maritime Cultures of the Sea of Okhotsk: Eskimo-Aleutian Influence, V Northern Ar- 
cheological Congress, Abstracts, December 11-14, 2019, Khanty-Mansiysk, Yekaterinburg - Khanty-Mansiysk, Alfa-Print, 175-177 [In Russian].

Lebedintsev, A. I.; Kuzmin, Ya. V., 2010, Radiocarbon Dating of Archaeological Sites of the Northern Okhotsk Region (Far East of Russia), The VI Dikov Readings: Proceedings of the Scientific Conference in Honor of the $85^{\text {th }}$ Anniversary of N. N. Dikov and the 50 th Anniversary NEISRI FEB RAS, Magadan, NEISRI FEB RAS, 116-120 [In Russian].

Li, Q.; Don, K.; Xu, L.; Jia, X.; Wu, J.; Sun, W.; Zhang, $X$.; Fu, $S$., 2018, The Distribution of Three Candidate ColdResistant SNPs in Six Minorities in North China, BMC Genomics, 19, Iss. 134.

Malyarchuk, B. A.; Derenko, M. V.; Denisova, G. A.; Litvinov, A. N., 2016, Prevalence of the Arctic Variant of the CPT1A Gene in Populations of the Indigenous Population of Siberia, Vavilov's Journal of Genetics and Selection, 20 (5), 571-575 [In Russian].

McGhee, R., 1979, The Paleoeskimo Occupations at Port Refuge, High Arctic Canada, Archaeological Survey of Canada, Mercury Series, Paper 92, Ottawa, National Museum of Man

McGhee, R., 1988, Origin of the Eskimos: Is an Alternative Hypothesis Possible? Sovietskaya Ethnografiya, 3, 110-118 [In Russian].

Milne, S. B.; Park, R., 2016, Pre-Dorset Culture, The Oxford Handbook of the Prehistoric Arctic, Oxford, 693711.

Movsesyan, A. A., 2012, Paleophenetic Analysis of the Modern and Ancient Population of Chukotka, Archaeology, Ethnology and Anthropology of Eurasia, 3, 130-137 [In Russian].

Pitulko, V. V., 1990, Economic and Cultural Type of the Late Neolithic Population of Chukotka, Early Sites of the North of the Nothern Far East, Magadan, NEISRI FEB AS USSR, 74-79 [In Russian].

Pitulko, V. V., 2001, Marine Adaptations in the NorthEast of Asia, Historic Readings: Proceedings of the Scientific-Practical Conference Devoted to 75 Birthday of Corresponding Member of RAS N. N. Dikov, Magadan, NEISRI FEB RAS, 64-71 [In Russian].

Pitulko, V. V., 2003, Holocene Stone Age of Northeast Asia, Natural History of the Russian East Arctic in the Pleistocene and Holocene, Moscow, GEOS, 99-151 [In Russian].

Popov, A. N., 2001, Complex of Bone, Horn, and Fang Fishing Tools of the Boysman Archeological Culture, Works of Art and Other Antiquities from the Monuments of the Pacific Region - from China to Honduras, Vladivostok, 36-54 [In Russian].

Popov, A. N.; Chikisheva, T. A.; Shpakova, E. G., 1997, Boysman Archaeological Culture of Southern Primorye (by Materials from the Multilayer Boysman II Site), Novosibirsk, IHAE SB RAS [In Russian].

Popov, A. N.; Rakov V. A.; Lazin B. V., 2011, Ancient Marine Fisheries in Southern Primorye (by the Materials of the Neolithic and Early Iron Age Shell Mounds), Novosibirsk State University, Bulletin, Series: History and Philology, 10 (7), Archeology and Ethnography, 140-145 [In Russian].

Powers, W. R., Richard, H. J., 1990, Human Biogeography and Climate Change in Siberia and Arctic North America in the Fourth and Fifth Millennia BP, Philosophical Transactions of the Royal Society of London, Series A, Mathematical and Physical Sciences, 330, 1615, 665670 .
Rasmussen, M.; Li Y.; Lindgreen, S.; Pedersen, J. S.; Albrechtsen, A.; Moltke, I.; Metspalu, M.; Metspalu, E.; Kivisild, T.; Gupta, R.; Bertalan, M.; Nielsen, K.; Gilbert, M. T.; Wang, Y.; Raghavan, M.; Campos, P. F.; Kamp, H. M.; Wilson, A. S.; Gledhill, A.; Tridico, S.; Bunce, M.; Lorenzen, E. D.; Binladen, J.; Guo, X.; Zhao, J.; Zhang, X.; Zhang, H.; Li, Z.; Chen, M.; Orlando, L.; Kristiansen, K.; Bak, M.; Tommerup, N.; Bendixen, C.; Pierre, T. L.; Grønnow, B.; Meldgaard, M.; Andreasen, C.; Fedorova, S. A.; Osipova, L. P.; Higham, T. F.; Ramsey, C. B.; Hansen, T. V.; Nielsen, F. C.; Crawford, M. H.; Brunak, S.; Sicheritz-Pontén, T.; Villems, R.; Nielsen, R.; Krogh, A.; Wang, J.; Willerslev, E., 2010, Ancient Human Genome Sequence of an Extinct Paleo-Eskimo, Nature, 463, 757-762.

Shilo, N. A.; Dikov, N. N.; Lozhkin, V. V.; Orekhov, A. A.; Tein, T. S., 1979, New Radiocarbon Dating of Archaeological Sites of North-East Asia, New Archaeological Sites of the North of the Far East (According to the North-East Asian Complex Archaeological Expedition), Magadan, SVKNII DVNC AN USSR, 9-11 [In Russian].

Sikora, M.; Pitulko, V.; Sousa, V.; Allentoft, M. E.; Vinner, L.; Rasmussen, S.; Margaryan, A.; De Barros Damgaard, P.; de la Fuente, C.; Renaud, G.; Yang, M. A.; Fu, Q.; Dupanloup, I.; Giampoudakis, K.; Nogués-Bravo, D.; Rahbek, C.; Kroonen, G.; Peyrot, M.; Mc. Coll, H.; Vasilyev, S. V.; Veselovskaya, E.; Gerasimova, M.; Pavlova, E. Y.; Chasnyk, V. G.; Nikolskiy, P. A.; Gromov, A. V.; Khartanovich, V. I.; Moiseyev, V.; Grebenyuk, P. S.; Fedorchenko, A. Y.; Lebedintsev, A. I.; Slobodin, S. B.; Malyarchuk, B. A.; Martiniano, R.; Meldgaard, M.; Arppe, L.; Palo, J. U.; Sundell, T.; Mannermaa, K.; Putkonen, M.; Alexandersen, V.; Primeau, C.; Baimukhanov, N.; Malhi, R. S.; Sjögren, K. G.; Kristiansen, K.; Wessman, A.; Sajantila, A.; Lahr, M. M.; Durbin, R.; Nielsen, R.; Meltzer, D. J.; Excoffier, L.; Willerslev, E., 2019, The Population History of Northeastern Siberia Since the Pleistocene, Nature, 570, 182-188.

Sørensen M., 2010, The Archaeology of Old Nuulliit: Eigil Knuth's Investigations in the Thule Region, North Greenland, 1952-1990, Copenhahen, Museum Tusculanum Press (Monographs on Greenland, 349).

Takase, K.; Lebedintsev, A. I.; Ptashinsky, A. V., 2012, New Radiocarbon Dates for the Northern Priokhotye and the Northeast Coast of Kamchatka, The $7^{\text {th }}$ Prof. Dikov's Conference, Proceedings of the Scientific Conference Dedicated to the $80^{\text {th }}$ Anniversary of Industrial Activities in Kolyma and the 100 th Anniversary of the East Arctic Sea Trade Route Discovery, Magadan, NEISRI FEB RAS, 139-143 [In Russian].

Tein, T. S., 1979, Archaeological Research on Wrangel Island, New Archaeological Sites in the North of the Far East (According to the North-East Asian Complex Archaeological Expedition), Magadan, SVKNII DVNC AN USSR, 53-63 [In Russian].

Tein, T. S., 1982, Excavations on Wrangel Island, Krayevedcheskiye Zapiski, 12, Magadan, 124-129.

Tein, T. S., 1983, Mystery of Chyortov Ovrag, Magadan [In Russian].

The Oxford Handbook of the Prehistoric Arctic, 2016, New York, Oxford University Press.

Vasilievsky, R. S., 2001, Genesis and Interaction of Cultures of the North Pacific, Archaeology, Ethnology and Anthropology of Eurasia, 3, 31-38 [In Russian].

Yamaura, K., 1980, On the Relationships of the Toggle Harpoon Heads Discovered from the North-Western Shore of the Pacific, Material Culture, 35, 1-19. 